\title{
Real descriptions: Reflections on native speaker and non-native speaker descriptions of a language ${ }^{1}$ \\ Felix K. Ameka
}

\begin{abstract}
There are 2,000 or 3,000 languages, for which we have no decent description, that will pass into disuse within the next few generations. Trained linguists are urgently needed to document them. In most cases native speakers can be trained as linguists but in many instances an outsider is required. (Dixon 1997a:138)
\end{abstract}

\section{Introduction}

Now more than ever in the history of linguistics with our growing awareness of the need to document and describe languages that have not yet been recorded, the importance and role of the native speaker has been brought into sharper focus. The native speaker is no longer merely seen in field linguistics as "a human being who is able to give information about his or her language" (Coulmas 1981: 5). They are rather seen as people who can help "shape the record" (Mithun 2001) or promote the work of the linguist through a healthy and symbiotic relationship of the kind described by McLaughlin and Sall (2001). The native speaker may also be the last repository of a significant body of knowledge which is a crucial component of the world's intellectual and cultural heritage (cf.Crystal 2000, Evans 2001). At the same time, it has become increasingly clear that there are different kinds of native speakers (see e.g. Dorian 1981, 1986 and Grinevald 2003; and see also Davies 2003 on the role of the native speaker in applied linguistics). Despite the recognition of a more active role for the native speaker in language description, discourses on documentation generally take it for granted that the linguist doing the documentation is an outsider-a non-native speaker of the language in question. Some will concede, as Dixon does in the quote above, that native speakers can also be trained 


\section{Felix K. Ameka}

as linguists to describe their native languages, but on the whole the assumption and practice remain what Ken Hale (of blessed memory) observed decades ago. He remarked: "It is a prevailing fact about anthropological linguistics that the linguist and the native speaker are not the same individual" (Hale 1972: 384). Moreover, he wondered about the future of a linguistics dominated by non-native speakers of languages they work on. $\mathrm{He}$ wrote:

I question whether significant advances beyond the present state of knowledge of the world's languages can be made if important sectors of linguistics continue to be dominated by scholars who are not native speakers of the languages they study. (Hale 1972: 385-386)

I am tempted to raise a similar question about the endangered languages documentation enterprise, if this task is only performed by "outsiders". In my view, if this trend continues we cannot expect to have optimal records or real descriptions of these languages. In fact, "insiders" are not always perceived as engaging in the "real" business of linguistics. I hope to demonstrate in this chapter that unless the records of the languages being documented are the product of collaboration between trained native speaker and non-native speaker (anthropological) linguists, they will not be real, or optimal descriptions representing the realities of the languages. This is because the issues attended to by the two kinds of linguists while overlapping in some areas, differ in others and yet are complementary in ways that are mutually beneficial to the documentation programme.

In the rest of the chapter I demonstrate the similarities and differences between native speaker and non-native speaker descriptions of a language by comparing the first descriptions of Ewe, a Kwa language of West Africa, by a non-native speaker (Westermann 1907, 1930) and by a native speaker (Ansre 1961, 1966a). Later descriptions by both kinds of authors are also considered (e.g. Clements 1972, Collins 1993, and Duthie 1996non-native speakers, and Ameka 1991, Essegbey 1994, 1999-native speaker linguists). It emerges that the descriptions are affected by the linguistic ideologies of the two types of linguists and differ in what they are sensitive to. For instance, a non-native seems to pay attention to generalisations in some areas and to be ethnographically rich while a native goes for details in other areas. I will illustrate this by examining the description of numerals and quantifier phrases, adjectives, aspectual constructions and verbal constructions. 
Of course, the time when a description is written bears upon the issues that are adumbrated in it. However this is orthogonal to whether the description is carried out by a native speaker or a non-native speaker. The types of questions raised in the linguistic literature, be it from practitioners who are working on formal or functional models of language or from typologically oriented linguists as well as the availability of information about the possibilities of human languages impact on the form, content and type of description. Furthermore, as we will discuss below, the type of training the linguist has received, be they native speakers or non-native speakers of the languages they are working on, affects their descriptive practice to a very large extent. While these features cannot be entirely disentangled from one another, I will, nevertheless, try to focus on the aspects of the descriptions that I consider to emanate from the native or non-native speaker status of the one carrying out the description.

The chapter is structured as follows. In the next section, the role of the native scholar in both ethnographic and linguistic description is discussed. Section 2 introduces the descriptions of Ewe that are compared. Section 3 suggests some of the concerns that are addressed in non-native speaker descriptions which are overlooked in native speaker descriptions. This is followed in section 4 by an examination of the pitfalls of native speaker descriptions. Section 5 discusses some of the common ground that is covered in both types of work. In the case of the Ewe works being compared, some remarks are made especially with respect to their being the foundation records of the language. Section 6 explores how subtle semantic distinctions can be lost on both native and non-native speakers and how such subtleties can be uncovered through a judicious use of native speaker intuitions, cumulative knowledge from earlier descriptions and corpus study. The final section concludes with the idea that we can only get a holistic and optimal description of a language if there is cooperation between welltrained native speaker and non-native speaker linguists of that language. The linguists should in turn collaborate with the naïve speakers of the language in the description and documentation enterprise.

\section{Native and non-native ethnographies and linguistic descriptions}

While linguists have not been too concerned with the appropriateness or otherwise of native speaker vs. non-native speaker descriptions of a language, anthropologists have debated at length the usefulness or otherwise 
of insider vs. outsider ethnographies (see e.g. Owusu 1978, Nukunya 1994 Yan 1997, Ryang 1997 Hastrup 1993, Abasi 1995). To set the scene for the discussion of the role of the native speaker linguist in language description, it is useful to recall some key issues in relevant anthropological debates. Some anthropologists have argued that since the main reason for doing ethnography is the experience of difference, "outsider" ethnographies are more suitable (cf. Pool 1989). In fact, Tedlock (1987: 329) suggests that there would not be "any place for an ethnographer if all parties shared the same native language ... What is ethnography if it is not the phenomenology of asymmetry, of otherness, foreignness?" From such a perspective insider ethnography is a contradiction. On the other hand, Owusu, who on occasion functions as an "insider" ethnographer $(1978,1997)$, is very critical of "outsider" ethnographers especially those who do not have much familiarity with the native language. Commenting on the earlier classical ethnographies of various African communities, he draws attention to the difficult position of the native anthropologist in working with such records. He notes that a careful reading of some of these ethnographic monographs demonstrates that

it is virtually impossible particularly for the native anthropologist to falsify, replicate or evaluate objectively. ${ }^{2}$ For frequently, it is not clear whether the accounts so brilliantly presented are about native realities at all or whether they are about informants, about scientific models and imaginative speculations or about the anthropologists themselves and their fantasies (Owusu 1978: 312 emphasis in original)

I believe native speaker linguists sometimes feel the same way towards some descriptions of their languages. The native speaker linguist is even in a more precarious situation when it comes to data quality control because the specific description can always be said to be the model and reality of the particular native speaker consultant. Furthermore, in linguistics, data from a native speaker is considered "sacrosanct" as Bickerton (1996: 157) quoted in Lefebvre (1999: 383) put it:

It is a foundation stone of our discipline that native speakers of a language do not and in the nature of things CANNOT 'correct', 'modify', 'rectify', or 'repair' the judgements of other native speakers: they just make different judgements (emphasis in original)

In a sense this is true and it can be an important safeguard against native speakers claiming their variety of a language to be the representation of the whole language. However, this can and has been misused to ignore native 
speaker judgements about particular sentences that have served as foundation stones for various formalisms. Sadock (1996) brilliantly satirizes this as a manifestation of the Principle of Information Free Linguistics (PIFL). One scenario he sketches is where a linguist, giving a talk on a much discussed language in the "theoretically central literature" called Tophar, cites the following relevant data with judgements to illustrate a hitherto undocumented possibility of covert scrambling at LF:

(i) a Pictures of themself seem to him to bother each other

b *Pictures of him seem to them to resemble each other

(ii) a Whose self do picture of each other bother him?

b *Where is the nearest men's room?

The challenge from a speaker of Tophar in the audience and Sadock's portrayal of the linguist's reaction is illuminating and worth quoting in extenso:

"I am a native speaker of Tophar [pronounced [dopHAR] - Oops!] ... and find your (ia and (iia) horribly ungrammatical and your (ib) and (iib) just fine. Doesn't that cast some doubt on your principle of LF scrambling?"

Uhhh, Noo. To the theoretically naive in the audience, the dispute over the accuracy of your data might seem pretty serious, but given the gigantic gulf between data and theoretically relevant fact and the further chasm between fact and principle, it is not really of any consequence. LF scrambling could well exist regardless of any data from Tophar or any other language, for that matter. Given what we know of UG, LF scrambling is a clear possibility, a virtual conceptual necessity, as a matter of fact. So in this case, simply smile patronizingly and say "My data are different from yours", for indeed they are. (Sadock 1996: 136)

A native speaker linguist's hands are tied, as it were. Sometimes, various claims are made about their language and different kinds of data are attributed to native speakers of their language, data that is hard to replicate. Sometimes it is even hard to see how the data and the judgements reported from native speakers support a particular theory that they are being used to demonstrate. For instance, Aboh (2001: 759) in a review of a book about a variety of his native language observes in a way similar to Owusu that a "close scrutiny of the data reveals that most of the examples relevant for the discussion are ungrammatical. Conversely, other examples which are perfectly grammatical are analysed by the author [a non-native speaker linguist 
FKA] to be ungrammatical". Yet a native speaker linguist like Aboh or myself can only say in such contexts that either the speakers we consulted on a particular piece of data accept it or reject it, or that the speakers have different grammars. One cannot repair or modify the data of another native speaker. They are just different data. It makes one wonder sometimes about the empirical bases of some theoretical claims (see also Lefebvre 2000 on data in pidgins and creoles research).

Be that as it may there are arguments for giving a role to the native scholar even in ethnographic fieldwork. Owusu (1978) adopts some of the views of David Schneider who discusses the reasons why native ethnographers have a role in the study of kinship in America. Schneider argues that a native ethnographer knows the society and culture well. He adds:

We speak the language fluently, we know the customs and we have observed the natives in their daily lives. Indeed we are the natives. Hence we are in a especially good position to keep the facts and the theory in their most productive relationship. We can monitor the interplay between fact and theory where American kinship is concerned in ways that are simply impossible in the ordinary course of anthropological work. ... By the same token of course we are able to achieve a degree of control over a large body of data which many anthropological fieldworkers hardly approach even after one or two years in the field. Hence the quality of the data we control is considerably greater and the grounds for evaluating the fit between fact and theory is correspondingly greater. (Schneider 1968 quoted in Owusu 1978: 321-2)

Comparable things have been said about the usefulness of native speakers in linguistics. Ulvestad (1981: 245-6), supporting his claim with a quote from Lees (1957), argues that:

... the most powerful research machine imaginable is the trained linguist who is also a native speaker of the object language. He is the ideal linguist par excellence; only he can be in possession of "those flashes of insight, those perceptions of pattern, which mark off the brilliant scientist from the dull cataloguer of data" (Lees 1957: 380).

Some, e.g van Driem (2002), would argue that this is demonstrably false. In support of their argument, they would assert that the best and most comprehensive grammars of English were written by non-native speakers, notably Danish and Dutch scholars, such as Jespersen (e.g. 1933, and see also his seven part English grammar), Kruisinga (1911) and Zandvoort (1948). Thus non-natives can acquire and appropriate, as it were, a high degree of native knowledge some of which the natives themselves are not 
native knowledge some of which the natives themselves are not conscious of. Widlok (2004) points out that such non-natives learning the language from outside as well as natives learning, or rather developing their competence, from inside tend to make similar mistakes, especially mistakes that are related to mismatches of frame expectations. Thus the distinction between native speaker and non-native speaker dissolves when they are participating in communicative practices. Nevertheless, I still think there are pieces of knowledge that the native speaker has which they may not be conscious of but which remain hidden from the non-native (cf. Keesing 1979).

Even this point may be challenged, however. Van Driem (2002: 12) cites Anna Wierzbicka as an example of a non-native speaker of English who has very subtle intuitions and can produce a battery of expressions to justify one or the other semantic analysis sometimes to the amazement of native speakers (cf. Wierzbicka 1988, in press). While this is true, it is also the case that Anna Wierzbicka constantly draws on the intuitions of many native speakers including linguists and linguists in training. Thus the product that one gets is the result of collaboration between Anna Wierzbicka, a non-native speaker, and a host of native speakers. Moreover, although the English grammars mentioned above are justifiably celebrated, it is my contention that one of the best, if not the best English grammar to date, is the one produced by a team of native speakers, Randolph Quirk, Sidney Greenbaum and Geoffrey Leech and a non-native speaker, Jan Svartvik, namely, Quirk et al. (1985) and see also Leech and Svartvik (1975, 2003).) This is what I advocate: a collaboration in the documentation enterprise between native and non-native trained anthropological linguists.

One reason why such collaboration is the optimal documentation team imaginable is that being a native speaker linguist is a mixed blessing. On the one hand, they may be the ideal linguist par excellence but they may also be the worst source of information on their native language because their intuitions may have become contaminated and biased by the theories that they work with. In fact, the native speaker linguist may not always be able to separate an empirical fact from a theoretical dogma that they are pursuing. The Janus-faced nature of a native speaker linguist or grammarian is commented upon by Anttila (1972: 349) as follows:

Once you have linguistic training, you spoil your native intuitions as a normal speaker and you cannot write a psychologically real grammar for a normal speaker. Linguists are not normal speakers when they write gram- 
mars. On the other hand if you are a naïve speaker you cannot write grammars at all.

One of the ways in which a trained native speaker is a danger to the language is where the fragments of the language they perceive to be good or bad pieces of the languages tend to be dictated by their own linguistic ideologies or specific varieties. This may be an ideology based on theoretical orientation, where the language is forced by the native speaker to become more like the translated versions of sentences used to justify claims about phenomena within a model such as long distance movement or verb movement. Or it may be based on the variety of the language that they speak themselves. One of the facts of life is that trained native speaker linguists tend to be people who live away from their language environments. As such they may not participate in communities of practice in which the language is one of the codes. They may thus have restricted codes since they may not use the language in some domains on a daily basis.

Some of these negative effects can be minimised with good training. Attention has been drawn to the need for reappraisal of the kinds of linguistics programmes that are currently available (Grinevald 1998; Newman 1998, 2003). Newman, for instance, chastises graduate linguistics programmes in American universities for not adequately catering for the needs of native speaker $\mathrm{PhD}$ candidates in terms of empirical scientific methodology. Let me point out that even if native speaker linguists are well trained in these methods, there is a peculiar problem that they might face in their language communities, namely, when they attempt to get information from other speakers they are told that they speak the language and they should not be asking such stupid questions. In this situation, the teacher - apprentice construct for field-work does not always work. What some of my colleagues and I have found useful in such situations is the use of stimulus based elicitation techniques as described by Hellwig (this volume); see also Ameka and Essegbey (2006, in press). We have also found it useful in our work on Ewe to draw on different kinds of mediated discourse such as creative written works produced by other native speakers, oral productions of drama, poetry etc. on the radio or television, and real-time observation and recording of conversations. Certainly these can be used by non-native speakers as well - see Duthie 1996 who uses texts from an Ewe newspaper as an important source of examples. But non-native speakers need a good knowledge of the language, and especially in the case of the written texts without fully explicit orthographies (Ewe orthography does not mark tones), one needs a good knowledge of the language to work through them. 
My experience as a trained native speaker linguist working on my native language contrasts with that of my work as an outsider working on Likpe, a Ghana-Togo Mountain language, whose speakers are bilingual in Ewe, the lingua franca, and in Likpe. Certain speakers also command Akan and English. Some of the constraints I feel include not being able to have a good feeling for the subtle intuitive differences that are encoded in the language which need to be tapped. In addition, I am not able to generate native-like texts of encoding idioms spontaneously, the way I can when I am investigating an issue in Ewe. Moreover, there is not much of the kind of mediated discourse mentioned above for Ewe that I can access. Nevertheless, it is because of the difference between the native and the non-native that I advocate collaboration not only between the two kinds of linguists as the optimal "research machine imaginable", but also between native speaker researchers and the normal speakers of the languages being documented. I believe my work on Likpe and the documentation that I can produce would be much much better if there were a trained native speaker linguist of the language to work with. I have a couple of very well trained consultants who understand the nature of linguistic work but it would be different if they were to have been formally trained in linguistics.

The rest of the paper is devoted to showing the subtle differences between native speaker and non-native speaker descriptions as reflected in the records that are available for Ewe. Before turning to the features of the description as such, I first provide some commentary on the context of the records to be compared.

\section{On the 'first' records and past records of Ewe}

The first descriptions of Ewe by non-native and native speaker grammarians belong to different phases in the history of Ewe linguistics. Clements (1972: 22) observes with respect to the first phase that it

... corresponds to the effort of creating a Standard Ewe by the members of the Bremen Mission, and includes a good deal of purely descriptive work of high quality. The dominant figure is that of Westermann, whose two monumental dictionaries $(1905,1954)$ span his active career as a linguist. Other studies include his grammar (1907, English translation 1930)...

It is Westermann's grammatical works which we consider to be the first record of Ewe by a non-native that we will mostly be concerned with in this chapter. These works constitute the most comprehensive grammatical de- 
scription of the language and have been the standard reference works on the language ever since. Different kinds of information from these grammars have found their way into databases for typological and cross-linguistic studies.

Clements (1972: 23) further observes that:

The second phase has been concerned largely with providing descriptive studies based on developments in structural and transformational linguistics. ... Among the more important studies ... have been Ansre's studies of tonal structure (1961) and grammatical units (1966a) and several papers on tone, morphology and syntax.

These works by Ansre on the phonology (1961) and grammar (1966a) together constitute the first description of Ewe by a native speaker on linguistic principles. And it is these that we will compare with Westermann's works.

Both of these first descriptions suffer from the theoretical and linguistic climate at the time of their production. For instance, Ansre, while acknowledging the importance of Westermann's work, notes that it has some disadvantages characteristic of its era: "Theoretical inconsistencies are not uncommon and many of the categories set up seem to have no basis except a notional one derived from other languages. There are attempts to connect forms by etymologies that cannot be substantiated" (Ansre 1966a: 16).

In a review of early descriptions of Ewe, I accorded a special place to the works of Ansre, especially the grammatical description of 1966a. However, I commented that

... the theoretical framework employed in the grammatical description Scale and Category, a precursor to Halliday's Systemic Functional Grammar - is outmoded and makes the work less accessible and relevant today. Nevertheless, it provides a good account of the structural properties of the language. (Ameka 1991: 5)

For these reasons, the comparison of the first records is not based on framework internal features but on substantive analytic issues that are required in a documentation that seeks to capture the 'genius' of a language.

\section{Concerns in non-native speaker descriptions of a language}

In this section, I will draw attention to three features of Westermann's description of Ewe which I see as properties of non-native descriptions. First, 
the non-native tends to be sensitive to features of the language that make a difference to $\mathrm{him} / \mathrm{her}$. Second there is a tendency to make generalisations focusing on a norm, downplaying variation.

Third, non-native descriptions might gloss over important features that relate to the specific semantic style or the encoding idioms of the language.

\section{(i) Sensitivity to specific features that make a difference}

Characteristic of his close attention to features that make a difference, Westermann includes in his grammar a description of Ewe gestures of counting. He notes:

The Ewe people count on the outstretched fingers, beginning with the little finger of the left hand, each being bent by the forefinger of the right hand as it is counted; the right hand is used next, and then one begins again, or else, squatting on the ground, one counts on the toes with the little finger of the right hand, so that we then have altogether an ameju' 'twenty'. (Westermann 1930:101)

It seems to me that since the way of counting on the fingers was different from what he was used to, Westermann was struck by the Ewe method of counting. I think that this kind of information is something that a native speaker will not easily identify as important information in a grammar. It is not all non-natives that are sensitive to this kind of information either. A perusal of different grammars on my shelf revealed that many grammarians do not say anything about the way counting is done even though they all devote pages to numbers and to quantifiers.

In discussing numeral constructions, Westermann also drew attention to two other issues in Ewe grammar. The first is the co-occurrence dependency between the numerals and the plural marker and determiners. $\mathrm{He}$ pointed out, using the parlance of his time, that when a noun is quantified by a numeral, the plural does not occur as in (1a). However when the quantified noun is determined, then the plural marker must occur, as illustrated in (1b). ${ }^{4}$ Compare

$$
\begin{aligned}
& \text { a. xo gấ eve (*wó) } \\
& \text { house big two PL } \\
& \text { 'two big houses' }
\end{aligned}
$$


12 Felix K. Ameka

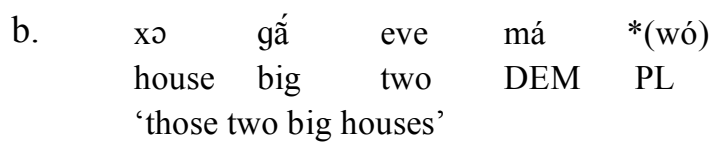

A second topic he addresses relates to the unit counter ame, a form which otherwise means 'person'. He does not use that label but mentions the use of the form together with the third person plural pronoun for counting pieces and copies (Westermann 1930: 99-100). Some languages in the same area as Ewe also have such unit counters but I have not found information on them in the available descriptions. I submit that Westermann as a non-native speaker was acutely sensitive to anything that might seem characteristic of Ewe.

\section{(ii) Interest in generalizations}

Westermann, in describing Ewe aimed very much at stating generalisations as implied in Ansre's critique, cited above, of the connections that Westermann was drawing between forms that Ansre would not necessarily want to link. But such interest in generalisation can sometimes lead to obscurity. Let me illustrate with a rather trivial example. In (2) I reproduce the tabulations of the object pronouns in Ewe by both Westermann and Ansre.

\begin{tabular}{|c|c|c|c|c|}
\hline \multicolumn{5}{|c|}{ Ewe object pronouns: } \\
\hline \multicolumn{2}{|c|}{ à la Westermann } & \multicolumn{3}{|c|}{ à la Ansre } \\
\hline m & me & Sing & 1 & m \\
\hline wò & you & & 2 & wo \\
\hline è & him, her, it & & 3 & $\mathrm{i} / \mathbf{e} / \varepsilon$ \\
\hline mí & us & P1 & 1 & mí \\
\hline mi & you & & 2 & mi \\
\hline wó & them & & 3 & wó \\
\hline
\end{tabular}

The form of interest to me here is the 3rd person singular pronoun. Westerman represents it simply as $\grave{e}$ while Ansre represents the three vowels and comments in a footnote that "The phonological form of the 3rd person singular here is determined by the last vowel of the preceding syllable" (Ansre 1966a: 143, fn 12). Even though it has been demonstrated in later work (e.g. Capo 1985) that the 3 singular pronoun is better captured as a clitic $-i$, it is clear that Westermann was striving for a more general state- 
ment without specifying further the details, while Ansre was more interested in representing the variants from which to draw generalisations.

\section{(iii) Glossing over some important features}

As noted earlier, Westermann's grammar is rather comprehensive, yet as a non-native speaker he missed some features of the language which one could say characterise the semantic style of its speakers. One such feature is the use of a form $-i$ to mark what one might call predications, in modern parlance (see Ameka and Schultze-Berndt 2000, Ameka 2005). One domain where this marker occurs is in certain types of serial verb constructions, especially those involving accompaniment. Talking about the use of the verb vá 'come' in contexts to mean 'to here' Westermann (1930: 132) notes that in such cases the form $v \varepsilon$ (from váe) is readily used instead of vá. $\mathrm{He}$, however, does not explain what the $-e$ form is in such contexts-and in fact, as we shall see, it is better seen as an $-i$ because it undergoes the same kinds of assimilation processes as the $3 \mathrm{SG}$ object pronoun form. One of Westermann's examples of this usage is:

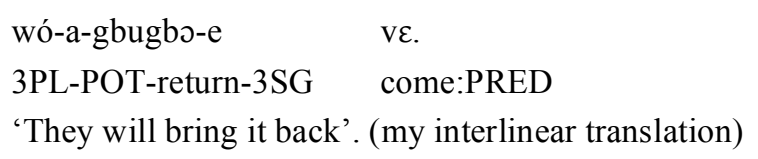

Ansre, however, noted that this form occurred with other verbs and not just $v a$ and offers a preliminary analysis for the $-i$ marker. He suggested that it is a redundant object marker:

When a particular sub-class of verb expounds the final P (i.e. Predicate FKA) element in the compound class, an element occurs with it the analysis of which has so far not been completed. This sub-class of verbs is designated Verbs of motion. ... The element in question is termed the Redundant Object (Ansre 1966a: 71).

In a footnote, he explains the term "redundant object" thus: "Redundant' because unlike other objects it has not been possible to establish that it operates as a complement in clause structure; 'Object' because in all respects it is phonologically identical with the third person singular object of the pronoun" (Ansre 1966a: 71). One of the examples illustrating the form is given in (4). 


$$
\begin{aligned}
& \text { É-tsó nyĕ ádáka dzó-e. } \\
& \text { 3SG-take 1SG:poss box leave-Redundant_Object } \\
& \text { lit: S/he has taken my box [and] left } \\
& \text { 'S/he has taken my suitcase away'. }
\end{aligned}
$$

It seems to me that Ansre was drawing on his native speaker intuitions and introspecting about parallel structures. This led him to discover other verbs that participate in the construction. Furthermore, he saw that the realisation of the morpheme was the same as that of the third person object pronoun, as he explained in the footnote. Ansre's initial analysis has served as basis for later investigations by both native and non-native speakers (see e.g. Clements 1972, Lewis n.d., Collins 1993, Amuzu 1993). The link that Ansre makes between the- $i$ marker and the 3 singular object pronoun seems to be historically founded but synchronically, it would appear that the two forms are different (see Ameka 2005). Furthermore, we owe it to Ansre's native speaker intuitions that this multifunctional marker, which has turned out to be typologically significant, was first brought to the attention of the linguistic community in a systematic fashion.

\section{The precariousness of native speaker linguist descriptions of a language}

By the same token, however, a native speaker could under-represent the variety of styles and expressive means available in the language by not taking account of variants beyond their own idiolect or dialect. This could be taken to extremes where a linguistic fragment from another dialect would be dismissed as not belonging to the language. Similarly, the automatic fashions of speaking that the native speaker takes for granted are seldom made explicit in native speaker descriptions. Furthermore, subtle semantic distinctions that are manifest in the use of forms that can occur interchangeably are glossed over by native speakers.

\section{(i) The problem of representativeness and the dangers of introspection}

Nasalisation of vowels is a thorny issue in Niger-Congo languages, including Bantu languages. One of the unresolved questions has been whether the proto-languages of different subgroups in the family contain an equal number of oral vs. nasalised vowels. This is also an issue in Proto Gbe, the im- 
mediate ancestor of Ewe (cf Capo 1991). One source of data for the Ewe varieties is Ansre 1961. In this work Ansre claims that mid vowels are not nasalised in Ewe. This statement seems to be only true for his own Pekigbe dialect of Ewe where, as Ansre (2000: 31) in later work observes, "the high mid back vowel is not nasalised, */o/"'. In many other dialects of Ewe nasalised mid vowels are distinctive. Thus some dialects have the word ló 'remove from fire' which is ló in Pekigbe. Other words with the nasalised high mid front vowel are $d z \tilde{e}$ 'red' and fé 'young'.

\section{(ii) Some language facts are taken for granted}

The automatic and self-evident nature of language use provides partial explanation for the inability of native speakers to articulate the tacit knowledge they have about subtle differences between forms. It is also partly responsible for the fact that native speakers tend to take important language facts for granted. Thus some facts, which may hold the key to important typological generalisations, are taken for granted in native speaker descriptions. A case in point is Ansre's (1966a: 168) description of the aspectual construction that, following Westermann, has been termed the "ingressive". This term is infelicitous with respect to the semantics of the construction as outlined immediately below. It is better to call it the prospective (cf. Essegbey 1999). The structure of the construction can be represented as follows:

$$
\text { Subject - Verb - Aspectual Phrase }
$$

Ansre mentions only the forms le 'be.at:PRES' and no 'be.at:NPRES' which he characterises as tense particles (see also Ansre 2000: 41) as the forms in the Verb position in the construction. Compare (6) a. and b.
a. $\quad$ Nyrue le
agble
yi gé.
uncle be.at:PRES
farm
go
PROSP
'Uncle is going to go to (the) farm'.
b. Nyrue no agble yi gé háfí míe-de.
uncle be.at:NPRES farm go PROSP before 1PL-reach 'Uncle was going to go to (the) farm when we got there' (Ansre 1966: 169)


We get a fuller picture in some non-native descriptions. Thus Westermann (1930: 80) says that "In the ingressive (i.e. intentional) /le/ [as in (6a) FKA] may be replaced by a verb of motion such as /vál /gbol 'to come', /yil 'to go'." (See examples below,) Interestingly, a description which is the product of cooperation between a non-native speaker and several native speakers offers a more adequate account. According to Rongier et al (1990: 112), "L'intentionnel est marqué par le nom locatif 'gé'. Le verbe locatif est variable. Les plus fréquents sont 'lè', 'no', 'yi' [...], 'dè' (aller) et 'gbona' (revenir)." See also Warburton et al. (1968).

Even though more empirically sound, the description by Rongier et al. does not offer any clues as to the semantics and usage conditions of the "variable locative verbs". The meaning conveyed by the construction varies according to the semantics of the element that fills the verb slot (see Ameka 1991, Ameka and Dakubu to appear). In a nutshell, when the verb slot is filled by either member of the locative BE.AT suppletive set le or $n s$ the construction expresses the notion that an action is imminent or is about to happen in relation to the reference time as in $(6 a, b)$ above and (7) below.

$$
\begin{aligned}
& \text { fífí, me-le ku-kú gé kpuie. } \\
& \text { now 1SG-be.at:PRES RED-die PROSP shortly } \\
& \text { 'Now, I am about to die shortly.' (Akpatsi 1980: 69) }
\end{aligned}
$$

When the verb is the habitual form of the directional verbs yi 'go' or $g b 0$ 'come.back', namely yi-na 'going' or gbo-na 'coming back', the construction is used to describe inchoative or change in progress states of affairs as illustrated in (8).

$$
\begin{array}{lllll}
\text { zã yi- } \quad \text { na } & \text { do-dó } & \text { gé. } \\
\text { night go } & \text { HAB } & \text { RED-fall } & \text { PROSP } \\
\text { 'It is getting dark.' } & \text { (Gadzekpo 1982: } & \text { 26) }
\end{array}
$$

However, when the verb slot is filled by one of the motion predicates tsó 'come.from', $y i$ 'go' and vá 'come', the construction has a motion-cumpurpose reading as in (9).

$$
\begin{aligned}
& \text { Kofí tsó } \quad \text { lã } \quad \text { de gé. } \\
& \text { NAME come.from fish remove } \\
& \text { 'Kofi has come back from fishing.' }
\end{aligned}
$$


As Clements (1972: 64) notes tsó 'come.from' in this context "is not completely free of spatial reference and its use implies that movement in space accompanies the action".

The verb in the construction can also be filled by the telic verb de 'reach' which has a strong default reading of motion and of 'have been to a place'. The prospective construction with this verb signals that the state of affairs characterised in the clause has not been consummated: it was attempted or nearly attained. The exact reading in a context can be reinforced by the use of modifying phrases. Thus with the use of a verb-noun collocation dó 'put' kpo 'log' plus a predication marker $-i$ realised in (10a) as $-e$ which means 'failed' then the reading that is selected is the attempted one, while with an approximation expression such as kloé 'almost', it is the nearly attained sense that is prominent as illustrated in (10) a and $b$.

a

$$
\begin{aligned}
& \text { éye wò-de vo-vo gé dó kpo-e. } \\
& \text { and 3SG-reach RED-free PROSP put log:PRED }
\end{aligned}
$$

'And she tried to be free but couldn't.' (Gadzekpo 1982: 14)

b é-fé yútí-gbalẽ de ba-biã gé klóé.

3SG-poss body-skin reach RED-macro.red PROSP almost

'Her skin was almost copper-coloured.' (Dogoe 1964: 11).

The prospective construction thus has at least four sub-constructions depending on the verb that occurs in it. One issue that has exercised the minds of grammarians about this construction is the status of the elements that occur in the predicate slot: are they verbs or are they auxiliary items (cf. Clements 1975, Fabb 1992). Acknowledging that bona fide verbs occur in the predicate slot in the construction paves the way for a more comprehensive treatment. When the full range of forms are considered, it would appear that it is more adequate to characterise the forms in the predicate slot as verbs. When only the 'be.at' suppletive set is considered there is a tendency to emphasise the auxiliary status. Neglecting to mention the other verbs can thus lead to biases in the analysis.

Another phenomenon in Ewe that has been approached in slightly different ways by native and non-native speakers is that of the so-called inherent complement verbs. They are first discussed in any serious way by Clements (1972) who, drawing on observations of a native speaker pedagogical grammarian writing in Ewe, introduces the phenomenon as follows: 
Baeta [1962] ... has drawn particular attention to the importance of idioms in the Ewe lexicon. She contrasts non-idiomatic verbs such as toto' 'mix up' whose meaning is relatively stable whatever its object with idiomatic verbs like $f$ ú which frequently form a single unit of sense with their object, so that the total meaning of the expression is a function of both elements together:
a. Kofí fú du
running
'Kofi ran.'
c. Kofí fú dzo
fire
'Kofi warmed himself.'
b. Kofí fú tsi
water
d. Kofí fú así nú hand thing
'Kofi swam.'
'Kofí slapped something.'
e. Kofí fú ta nú yú
head thing outside
'Kofi set about something.'

She proposes the term 'helping noun' ... to distinguish such lexically specified nouns from unspecified ones. (Clements 1972: 206)

It is verbs like fú 'move limbs in a medium' which have come to be known as inherent complement verbs. One sense in which to understand the idiomaticity of the verb-noun collocations is in the sense of encoding idioms à la Makkai (1972) where the interpretation of the collocation can be compositionally derived. Nevertheless such idioms have to be learned.

Perhaps because it is possible to interpret them compositionally, Ansre (1966a) did not mention them. When I recently asked him about this "omission" he said that he did not see anything special about these verbs, i.e. nothing different between what Baeta calls non-idiomatic and idiomatic verbs in Ewe. Here we have one native speaker (not necessarily a trained linguist) being influenced by the difficulty of rendering some verbal expressions into English and therefore calling them idiomatic, and another native speaker, trained in linguistics, not seeing them as special or idiomatic. Because the mode of expression is different from the one familiar to him as a non-native speaker, Clements devotes special attention to it. Thus native speakers depending on their training can produce different descriptions with different interpretations of the facts of their language. Indeed one 
could interpret the form fú tsi as 'to swim' as being derived from the meaning of the verb 'move limbs in a medium' where the object specifies the medium as water. Using pragmatic principles of various kinds such as the neo-Gricean Informativeness and Quantity heuristic principles (Levinson 2000) one can understand the phrase as meaning 'to swim'.

In a sense, Ansre's intuition has been confirmed in an extensive study of these verbs by another native speaker James Essegbey (Essegbey 1999). He shows that verbs with general semantics tend to obligatorily require a complement to restrict their application. Furthermore, Ewe, he argues, is a "hypertransitive" language with a substantial part of the verb lexicon requiring a complement for the expression of various meanings. The complements in such structures are bona fide objects. They can be promoted to subject function in a capability experiential passive-like construction. Thus to express an idea like 'Kofi enjoys swimming' an alternative construction to Kofi fu' tsi 'Kofi swam' is used with tsi 'water' as subject and Kofi coded as an oblique dative object, as in (11).

$$
\begin{array}{lll}
\text { Tsi nyá fú-ná } & \text { ná } & \text { Kofí } \\
\text { water MOD move.limb-HAB } & \text { DAT } & \text { NAME } \\
\text { Lit: water is limb-moveable for Kofi' } & & \\
\text { 'Swimming is enjoyable to Kofi.' } & &
\end{array}
$$

Similarly, such verb plus complement phrasemes can take a further object and the resulting construction is a double object construction as in Kofí fú así nú (lit: Kofi move-limb hand thing) i.e. 'Kofi hit his hand against something'. Such structures conform to one type of double object construction in the language. This can be demonstrated by the nominalisation of the verb phrase involving the two objects where the first object is preposed to the verb and the second object appears adjoined to it as in the prospective aspectual sentence in (12).

$$
\begin{array}{llll}
\text { Kofi le asi } \quad \text { ú } & \text { gé nú. } \\
\text { NAME be.at:PRES hand move-limb } & \text { PROSP thing } \\
\text { 'Kofi is going to hit his hand against something'. }
\end{array}
$$

Furthermore, the complements can be pronominalised and since they have object functions they are realised in the objective form as in (13a) where 
the first object is pronominalised and in (13b) where the second object is pronominalised.

$\begin{array}{lll}\text { a. } & \text { Kofi } & f u ́-i \\ & \text { NAME } & \text { move_limb-3SG thing }\end{array}$

'Kofi hit it (sc. his hand) against something'

$\begin{array}{llll}\text { b. } & \text { Kofi } & \text { fú } & \text { así-i } \\ & \text { NAME } & \text { move_limb } & \text { hand-3SG } \\ \text { 'Kofi hit his hand against it' } & \end{array}$

It turns out, therefore, that something that seemed so obvious to a native speaker and therefore was ignored has something to say about transitivity. There is a strong suggestion that because of the behaviour of the so-called inherent complement verbs Ewe and similar languages of West Africa fall outside typologies which see languages as fundamentally intransitive or fundamentally transitive (Nichols 1982, Nichols et al 2004). For the same reason, it appears that these languages make use of two place constructions in spontaneous discourse more than has been reported for, say, English by Thompson and Hopper (2001).

\section{The contributions of "first" records}

In the foregoing sections, I have indicated some tendencies that we find in native speaker and non-native speaker descriptions that make them different. In this section I want to correct the impression I may have created that there was no common ground between the two types of descriptions. With specific reference to the works of Westermann and Ansre that are the focus of this chapter, one important feature that they share is that they are the foundation descriptions of Ewe by a non-native speaker and a native speaker respectively. Their impact on Ewe linguistic description and general linguistic theorising is enormous and similar, as will become evident in the course of this section.

\section{(i) They foreshadow a lot of current theoretical discussion}

As foundation records, the descriptions by both Westermann and Ansre set the agenda for further investigation, either singularly or when their views 
are taken together. Sometimes both authors give opposing views, which allow for exploration of the facts. Two areas where the works of Westermann and Ansre have provided meat for research are on the adjective category and on serial verb constructions and grammaticalisation both in Ewe and cross-linguistically. I will take each of these in turn.

(a) The adjective category in Ewe

Westermann (1930: 183) sums up his view on the adjective category in Ewe as follows:

There are no words which are adjectives pure and simple. All expressions which serve as adjectives are either (1) also substantives or formed from substantives or (2) actually verbs or formed from verbs or (3) combinations of verbs and substantives or (4) also adverbs or (5) picture words [i.e. ideophones FKA]

Ansre (1966a: 213) counters this view by commenting that:

The assertion by Westerrmann that "there are no words which are adjectives pure and simple" is inaccurate and must be attributed mainly to lack of sophistication in tonal analysis and too great a tendency to etymologise.

However, Ansre's treatment in which he distinguishes between simple and multi-morphemic adjectives also obscures the important distinction between ideophonic and non-ideophonic adjectives in the language. The multi-categorial nature of ideophones is such that forms that may be categorised as adjectives can also function without any change in form as verbs, adjectives or adverbs depending on their syntactic position in the clause. It is this behaviour that is probably partly responsible for what Westermann says about adjectives. Thus one of the simple adjectives that Ansre gives can function as an adjective in (14a), a verb in (14b) and an adverb in (14c).
a.
$\begin{array}{llll}{[\text { nútsu }} & \text { tralaa } & \text { lá }]_{\mathrm{NP}} & {[\text { vá }]_{\mathrm{VP}}} \\ \text { man } & \text { thin.and.tall } & \mathrm{DEF} & \text { come }\end{array}$
'The tall and thin (lanky) man came.'
$\begin{array}{ll}\text { b. } \quad[\text { yútsu } & \text { lá }]_{\mathrm{NP}} \\ \operatorname{man} & \mathrm{DEF}\end{array}$
$[\text { tralaa }]_{\mathrm{VP}}$
man DEF
thin.and.tall
'The man is tall and thin (lanky)' 


$$
\begin{aligned}
& \text { c. } \quad[\text { yútsu lá }]_{\mathrm{NP}} \quad[\mathrm{kó}]_{\mathrm{VP}} \quad\left[\begin{array}{l}
\text { tralaa }]_{\mathrm{AP}} \\
\text { (n) }
\end{array}\right. \\
& \text { man DEF be.tall thin.and.tall } \\
& \text { 'The man is tall in a tallish-thinny (lanky) manner.' }
\end{aligned}
$$

Later research has established that apart from the ideophonic adjectives of the kind illustrated in (17a), Ewe has a small set of non-ideophonic underived adjectives. There are five such adjectives. They are listed in (15).

$\begin{array}{lllll}\text { gã } & \text { 'big' } & \text { ví } & \text { 'small' } & \text { (DIMENSION) } \\ \text { võ } & \text { 'bad' } & & \text { (VALUE) } \\ \text { yí } & \text { 'white' } & \text { dzĩ / dzẽ } & \text { 'red' } & \text { (COLOUR) }\end{array}$

Thus, contra Westermann, there are adjectives pure and simple in Ewe.

In addition, Ewe has a plethora of processes for deriving adjectives: suffixation as in (16a), reduplication as in (16b) and compounding as in (16c).

(16) a. the addition of a deverbal adjectivalising suffix $-i$ to a verb nyó 'become good' $+i \rightarrow$ nyóé / nyúi 'good' (Adj)

b. verb reduplication where the copy maintains the tone of the stem plus the addition of a high tone suffix (HTS), indicated here and in (16c) by an acute accent after the word.

fá 'become cold' + RED + HTS $\rightarrow$ fáfá' 'cool, cold' (Adj)

c. compounding of a verb and its complement plus a high tone suffix

nyá 'come.to.know' + nú 'thing' + HTS $\rightarrow$ nyánú' 'clever' (Adj)

The derived adjective in (19a) nyóé / nyúi 'good' has taken on the properties of the underived adjectives such as nominalisation by Low tone prefix probably in order to fill the gap in the VALUE terms in the system of underived forms (see Ameka 1991, 2001 and 2002). 
(b) Serial verb constructions and grammaticalization

Anybody familiar with the literature on serial verb constructions will be struck by the perceptive comments that Westermann (1907) made about this phenomenon in Ewe.

Eine Eigentümlichkeit des Ewe besteht darin, daß es gern eine Reihe von Verben unmittelbar aufeinander folgen läßt ... Im Deutschen werden diese aufeinanderfolgenden Verba zum Teil durch zusammengezogene Sätze oder Satzgefüge wiedergegeben. Sehr oft können aber auch mehrere Verba des Ewe im Deutschen durch ein einziges ausgedrückt werden. Der Eweer beschreibt nämlich jede Handlung, jeden Vorgang in allen Einzelheiten von Beginn bis zum Ende and drückt jede solche Einzelhandlung durch ein besonderes Verbum aus; er zerlegt jede Handlung in ihre Teile und bringt jeden Teil für sich zur Darstellung, während wir im Deutschen nur die Haupthandlung herausgreifen und sie durch ein Verbum ausdrücken, während alle Nebenhandlungen entweder ganz unberücksichtigt bleiben oder mittels einer Präposition, eines Adverbs, einer Konjunktion oder einer Vorsilbe des Verbum etc. wiedergegeben werden. (Westermann 1907: 9495)

The description and explanation offered in both the German and English versions have influenced and generated research in serial verb constructions not only in Ewe and other West African languages but also in Creole languages (e.g. Sebba 1987). To my knowledge there has not been any more sophisticated explanation given for the phenomenon of serialisation than the one given above here. Furthermore, the issues that continue to be debated in the literature follow from those raised in Westermann's (1907, 1930) quote above: Do serial verb constructions (SVC) code single events? Which arguments do verbs in an SVC have to share? Do all arguments have to be realised? Do verbs in an SVC have to share the same tense and aspect? (See Dechaine 1993, Durie 1997, Crowley 2003, Ameka 2003, 2006 for overviews of some of the current issues.)

Similarly, even though Westermann had already observed the process of grammaticalisation of verbs in progress (Westermann 1930: $129 \mathrm{ff}$ ), it was Ansre who cautioned that it is not every combination of verb forms in a clause that should be considered a serial verb construction (see especially Ansre 1966b). He suggested that the verb forms which did not occur with the full set of verbal properties, when in combination with other verbs, be 


\section{Felix K. Ameka}

called verbids. By this he launched a further search for defining criteria of SVCs and of the properties that determine verbal status in an SVC (cf. Bamgbose 1974, 1982, Essegbey 2004) and see also the cross-linguistic exploration of this issue in Lord (1993), for example.

The records of Westermann and Ansre on Ewe have thus laid the foundation not only for further exploration of Ewe linguistic structures, but also for cross-linguistic and typological studies. They have enduring relevance.

\section{(ii) They tend to be incomplete in their coverage}

Despite their enduring relevance, the records by Westermann and Ansre are also similar in providing restricted coverage of some topics, data and analyses. A case in point is the account provided for the perfective adverbial marker $v o$ which is a grammaticalised form of the verb vo 'finish'. The perfective marker is described as signalling the completion of a state of affairs characterised in the clause. A few important things are left implicit or not mentioned at all. First, as a marker of completion, it predictably does not co-occur with states. Second, the perfective marker has a vague reading when it occurs with processes that have a terminal end point: it can either mean the situation has been completed or is about to be completed, as illustrated in (17).

$$
\begin{aligned}
& \text { Míe-dó afé vo } \\
& \text { 1PL-arrive home PFV } \\
& \text { 'We have arrived at home.' / 'We are about to arrive at home.' }
\end{aligned}
$$

Third, the perfective marker can be triplicated to signal without any doubt the imminent completion rather than the total completion of an event. Thus if the perfective marker in (17) were triplicated the only interpretation possible is as shown in (18), see Ameka (1988) for further details.
(18) Míe-dó
afé vovos-vo
1PL-arrive home TRIP-PFV

'We are about to arrive at home.' 
(iii) They tend to become canonised and their misanalyses etc. are repeated

One of the most dangerous things about authoritative and influential foundation records of the kind that are being compared in this chapter is that their misanalyses which pertain to some theoretical or typological point are repeated over and over again in the literature. What is even worse is that theories and generalisations are built on such mistakes. These are very hard to correct. One example from the work of Westermann which has found its way into the grammaticalisation literature relates to the putative development of an adverbial particle dí 'down' from a verb di 'go down, descend' (see e.g. Heine et al. (1991, 1993); Lord (1993:228); Heine and Kuteva (2002)). The careful reader would have noticed the difference in tone and also noted that tone is distinctive in Ewe. The tonal difference between the two forms is reflected in Westermann's representation: He represents the verb form without any diacritic indicating that it is a low tone verb, but in the sentence that is meant to exemplify the grammaticalised form of the verb, the form is marked for high tone. This is reproduced below.

di to go down, to lay down, after another verb often means down and also beforehand; in such cases it is not conjugated [i.e. it does not take any verbal markers such as the potential as in (19) FKA]

$$
\begin{aligned}
& \text { ma-tsóe } \quad \text { (á)-da } \quad \text { dí. } \\
& \text { 1SG:POT-take-3SG } \quad \text { POT-throw down } \\
& \text { 'I shall put it down' (Westermann 1930: 130; interlinear gloss added FKA) }
\end{aligned}
$$

Drawing a link between two forms that have different tones could be seen as an example of the lack of attention to tonal differences that Ansre criticised Westermann for. Westermann did not make any comment about the difference in tone between the two items. Even though he did not do this, the modern analysts who cite these forms should have been struck by the tonal difference and it should have made them raise questions. But no, the same example is repeated over and over again to illustrate a development that is conceptually motivated and is attested in other languages. ${ }^{10}$ My point here is that Ewe does not provide an example for this grammaticalisation chain. The only reason this example is so prevalent in the literature is because it can be traced to Westermann who is otherwise a good source of 
data. It seems to me that a well-trained native speaker who can draw on their intuitions and feel the difference between the two forms would be less likely to copy such a mistake. The grammaticalisation theorists can be forgiven for not having access to such intuitions. But they cannot be forgiven for uncritically perpetuating a misanalysis.

Observe that establishing that two or more forms are related via grammaticalisation involves first identifying their forms. If the forms are the same but have functions that are conceptually related then one can be sure. If the forms are different, as is the case with the $d i$ and $d i$ forms, then unless one can demonstrate that the forms can be linked by some independent morpho-phonological process, one cannot claim that one evolved from the other. In the case at hand, it would be necessary to explain the source of the high tone on the supposed new form. Justifying such links requires more than just being a native speaker. It requires some training and also some knowledge of how things work in other languages.

From the vantage point of a trained native speaker linguist, I suggest that the adverbial particle $d i$ ' 'down' is not related to the verb $d i$ 'to go down' but rather to the preposition dé 'ALLative' (that ultimately is the grammaticalised form of the verb dé 'reach, enter'; see Ameka 1995, Aboh et al. in press for the details). The particle is the result of the fusion between this prepositional form and the ambient pronominal $-i$. An alternative and a synonym of the sentence in (19) is (20).

$$
\begin{array}{llll}
\text { ma-tsóe } & \text { (á)-da } & \text { dé } & \text { anyí. } \\
\text { 1SG:POT-take-3SG } & \text { POT-throw } & \text { ALL } & \text { ground } \\
\text { 'I shall put it down.' } & & &
\end{array}
$$

In (20) the complement of the allative preposition is the generic and ambient nominal anyi 'ground'. The idea is that the pronominalised form of the prepositional phrase dé anyi 'towards the ground' is $d i$ 'down' which comes from $d \dot{e}-i$ 'ALL-i'. The derivation of the $d i$ 'down' form from the preposition plus the ambient pronominal is rather simple. First, as a general rule, when two vowels occur in a sequence of this kind the underspecified vowel /e/ tends to be elided and if the tone is High it is maintained and absorbs the tone of the subsequent vowel. This is what has happened in this case. In fact a similar thing happens with the realisation of the prepositional phrase dé anyí in (20), which is pronounced [dányí]. Thus the vowel /e/ is elided and the $i$ form of the pronominal takes its place and its tone. Second, and this is to motivate the case for the ambient pronominal: the ambient 
pronominal tends to be used in other contexts in place of the generic nominal anyi 'ground'. For instance, there is a parallel between the two forms in the expression of existence. For generic and present existence the form $l i$ 'exist' is used, which is the result of the fusion of le 'be.at:PRES' and the ambient $-i$, and for past existence the non-present form of the 'be.at' verb $n$ o is used with the generic nominal complement anyi 'ground'. Compare the sentences in (21).
a. $\quad$ ga li.
money be.at:3SG
'There is money.'
b. ga no anyí tsấ
money be.at:NPRES ground formerly
'Formerly, there used to be money.'

In my view, there is a more interesting grammatical change process here which has not been talked about in the literature, just because the analysts failed to spot the mistake in Westermann. What is disturbing is that grammaticalisation experts seem to have accepted as an article of faith any example of a plausible development without arguing for each case in its own terms, and from the language internal point of view. Beware of foundation records or any records, they may contain some inaccuracies!

To minimise 'mistakes' of this kind being circulated in the linguistic literature, we need good training for linguists. We also need collaboration between trained native speakers and non-native speakers to draw out the "soul" of the languages being described. I will return to this issue of training in the conclusion. Before that, I want to illustrate the advantages of such a vision by discussing the analysis of disjunction markers in Ewe. It will emerge that native speakers on their own and non-native speakers on their own give only partial accounts of the forms, but with a cumulative understanding of the issues based on both traditions and with a better appreciation of the distinctions involved, a more holistic picture of disjunction marking in Ewe is attained. 


\section{An illustration}

Bolinger (1977: ix) observes that any word or construction that a language permits to survive must make its semantic contribution, however subtle (see also Wierzbicka 1988). Yet both native speakers and non-native speakers tend to overlook such distinctions and are content with saying that forms are used interchangeably. Sometimes this is because the distinctions are rather minute. This attitude may be a shortcoming of both native speaker and non-native speaker grammarians, as I will show immediately below. However, I consider it to be a more serious problem in native speaker descriptions since as was cited above, the native speaker is expected to have "those flashes of insight" which should make a difference. The native speaker should be able to give some comments on forms that seem to be used interchangeably. The non-native can be forgiven for not having those intuitions. And this is prima facie case for collaboration between both native and non-native speaker linguists.

I illustrate this with the treatment of disjunction in various descriptions of Ewe. Duthie (1996: 47) sums up the issue as follows: "The alternation [between noun phrases] is usually marked by aló or lóo aló". Westermann (1930: 111) suggests that the double form tends to occur in interrogative contexts. As he put it: "In questions aló is often preceded by lóo".

These statements from non-native speakers are a bit more instructive than what we get from some of the native speakers. Ansre (1966a: 134-5) suggests that the two forms are free alternants: "aló has an abbreviated form lóo with which it freely alternates." Similarly, Kangni (1989: 45), a native speaker of Gen, the neighbouring Gbe variety of Ewe, in which disjunction is also marked in identical ways to Ewe, comments as follows on the Gen situation:

[le disjonctif aló] sert á marquer la disjonction ou l'alternative. Pour souligner le contraste dans la choix il est souvent précédé du morphème emphatique lóó. C'est avec cette combinaison que nous le trouvons dans les énoncés interrogatifs.

The difficulty with these accounts is that they are half-truths and more seriously that there is no attempt to explain the so-called free variation or cooccurrence between the forms. In fact when one examines the use of these forms in discourse, it becomes apparent that there are actually three forms for marking disjunction in Ewe and Gen. 
The first is the form aló, whose message is that the choice of one alternative or the other in the context does not make a difference to the overall point being made. For this reason the alternatives that it links are either synonyms or paraphrases of each other. For example, both disjuncts in the excerpt below refer in the context to the same body part - the back- but they have different perspectives. Dzime, literally 'containing region of the heart', is the general word for the combined chest and back region on the body. In particular uses, the front part or the back part can be highlighted. By contrast, tume, literally 'the containing region of the liver' refers exclusively to the back part of the body.

$$
\begin{aligned}
& \text { É-ga-xo abi búbu hã dé é-fé dzime aló tume. } \\
& \text { 3SG-REP-get wound other also ALL 3SG-poss torso DISJ back } \\
& \text { 'He also received another wound in his chest or back.' }
\end{aligned}
$$$$
\text { (Ayeke } 1974 \text { [1283]) }
$$

The second disjunctive marker is lóó. It is used to link alternatives where the speaker does not know which of the choices is the case. This has an ignorative sense associated with it as in:

$$
\begin{aligned}
& \text { Dze ka-wó Hobianu dó ná wo le fulélé } \\
& \text { conversation CQ-PL NAME set DAT } \\
& \text { si le éfG LOC enmity } \\
& \text { REL be.at:PRES } \\
& \text { 3SG and person INDEF among } \\
& \text { tsó ga-nya ló nyónu-nya ádé yútí? } \\
& \text { ABL money-matter DISJ woman-matter INDEF outer.surface }
\end{aligned}
$$

'What conversation did Hobianu have with you about an enmity between him and someone else either because of financial or love matters?'

(Ayeke 1974 [399-400])

Because of the ignorative sense lóó tends to be combined with aló as a linker between two things, one or both of which could be assumed to be the relevant one in the context, but the speaker is not certain of this. For example, a detective is trying to probe the memory of his addressee to see 
whether she would remember any conversations with her grandfather that would give some clues to the motives of his killer in the excerpt in (24).

$$
\begin{aligned}
& \text { â-té yú á-nyé fi-nya } \\
& \text { 3SG:POT-press skin POT-COP theft-matter } \\
& \text { lóó aló ame-wu-nya búbu hã faa. } \\
& \text { DISJ DISJ person-kill-matter other also freely } \\
& \text { 'It could be a theft case or even a murder case.' (Ayeke } 1974 \text { [1405]) }
\end{aligned}
$$

This is what has led to the use of the third form of the disjunction marker lóo aló in interrogative contexts, as pointed out by Westermann, as in (25). Not surprisingly, the double form is used in embedded contexts introduced by knowledge related verbs as well.

$$
\begin{aligned}
& \text { To dzí-é ló, aló ya me-a? } \\
& \text { River upper.surface-aFOC DISJ DISJ air containing.region-Q } \\
& \text { 'Is it on sea or is it in the air?' (Hlomatsi 1994 [2866]) }
\end{aligned}
$$

Some support for these claims comes from the other uses of the markers independent of each other: the lóo marker is used as an utterance final particle marking propositional questions and aló is used as a disjunctive tag as illustrated below (see Ameka 1998).

$$
\text { Xomekú biá-e bé ye sro-é gblo nya má-wó ne lóó? }
$$

NAME ask-3SG QV LOG spouse-a FOC say word DEM-PL to:3SG DISJ

'Xomeku asked him if it was her husband who told him those things or?' (Ayeke 1974 [2604])

$$
\begin{array}{lcc}
\text { mía-da } & \text { te-a, } & \text { aló? } \\
\text { 1PL-cook } & \text { yam-DEF } & \text { DISJ } \\
\text { 'We will cook the yam, or?' (an overheard question) }
\end{array}
$$

Furthermore, aló is used as a discourse connective introducing or linking following propositions as alternatives to the preceding ones. For instance, in excerpt (28), a detective is wondering about the circumstances surrounding a murder and weighing different possibilities. The proposition immedi- 
ately preceding the excerpt translates as: Even though he was very strong because he was properly fed, when he died people would just say he has gone back home:

$$
\begin{array}{llll}
\text { Aló mé-le } & \text { é-me } & \text { nenémá } & \text { o-a? } \\
\text { DISJ 3SG:NEG-be.at:PRES 3SG-containing.region } & \text { thus } & \text { NEG-Q } \\
\text { 'Or is it not so?' (Ayeke 1974 [1897]) } & &
\end{array}
$$

It should be evident that one cannot describe these forms as mere variants since they each have a life of their own. Admittedly, the kinds of subtle distinctions that I have pointed out here are not easy to discover. Nevertheless a native speaker should be able to use a combination of introspection and corpus study to untangle such differences. For this the native speaker needs to be trained in how to use corpora and also to have some idea about the way other languages work. For instance, some knowledge of the crosslinguistic occurrence of grammatical polysemies involving disjunction and interrogative functions e.g. as occurs in Akan, or of disjunction and attitudinal marking functions, e.g. as occurs in German would provide reinforcing evidence for the analysis of the Ewe disjunction markers outlined here.

Perhaps this illustration provides an indirect clue as to how collaboration between trained native and non-native speaker linguists might work in the description of a language. Mosel (this volume) points out a practical approach to the mode of description that could be adopted in grammar writing independent of whether the grammar writer is a native speaker or a nonnative speaker. It seems that if the team of grammar writers is made up of trained native speaker and non-native speaker linguists it might be useful for the non-native speaker to tackle the structural or semasiological aspects while the native speaker contributes the onomasiological aspects. Then the roles can be reversed. An element of this mode of collaboration seems to be implied in the comments of Miestamo (2004) in a recent review of Blackings and Fabb (2003). He attributes a praiseworthy feature of the grammar to the fact that it is the product of both a native speaker (Blackings) and a non-native speaker (Fabb). He notes:

Often several alternative translations are given below examples. This welcome practice, rarely seen in reference grammars, highlights the fact that isolated examples can have different interpretations in different contexts. This is of course made possible by the fact that one of the authors is a native speaker (a grammar written by nonnative speakers is more dependent on the 


\section{Felix K. Ameka}

translations taken from the real discourse contexts of the examples). (Linguist List issue 14.3284)

There is some advantage in native speaker and non-native speaker collaboration.

\section{Conclusion}

An important task of linguistics in the present millennium is the description and documentation of the languages that are still around. Such descriptions should be of very high quality-they should be faithful to the data and they should be theoretically informed. Above all they should be presented both in terms of the metalanguage of description and in terms of the records in ways that are long lasting, replicable and verifiable. This is the only way to preserve the linguistic part of the world's cultural heritage in its diversity. What kind of linguist is the best to undertake such a job? Some would say a trained native speaker linguist. Others would say a trained non-native speaker linguist. I will continue to say the real description, the optimal record of a language, is the outcome of a collaborative effort, not only between trained native and non-native linguists but also between these linguists on the one hand and the normal speakers of the language. I have indicated the differences and similarities between the descriptions of both types of linguists. I hope I have thereby made the case for the need for collaboration between both types of linguists. I am not the first to have suggested this. The eminent linguist Eugene Nida makes a similar case for collaboration between linguists, be they native speakers or non-native speakers, and trained consultants. He writes:

... collaboration between a linguist and a trained informant can result in significantly more satisfactory results. This is not merely a matter of two heads being better than one, but of collaboration between two persons with complementary skills and knowledge ...

Even when a linguist is working on his own mother tongue it would be important to check items constantly with a trained informant (Nida 1981: 173)

Many non-native linguists are aware of their limitations and gladly defer to native speaker linguists to probe certain aspects of the language that they think require native speaker expertise. Recently, Bob Dixon conceded that 
he could not discover a distinction in the nominal system of Jarawara, a language of Brazil that he has written a grammar of. He thought "a well trained native speaker linguist might be able to find the difference, I cannot." This comment was made during a presentation at the International Workshop on adjective classes at the Research Centre for Linguistic Typology, La Trobe University (August 2002), (see Dixon 2004).

Throughout the chapter, the point has been made that the linguist, be they native or non-native speakers of the languages they are describing, should be well trained. One may well ask how this training should be carried out. I wish to end the chapter with the words of wisdom of Mary Haas who has been described as a "real linguist to the nth degree" (Dixon 1997b). She trained many linguists and produced many descriptions of languages. Unless linguists, whether they are working on their own language or another language, are exposed to other languages and are trained in analysis and argumentation, and unless there is collaboration between non-native linguists and trained native speakers, there is no hope that the records that are being produced will serve the purposes for which they are much needed. It is my hope that linguistics departments in universities around the world will incorporate some of the ideas articulated here by Mary Haas in their curriculum:

... a student's primary task should be to learn to analyse and describe a language. ... Although a semester's study of "a particular language" is very valuable, some one language should preferably be studied over a considerable period of time. ... this should be a language other than one's native language - even better, a language unrelated to one's native language. Notice how this contradicts one of the principles that was so heavily stressed a few years ago, namely that only a native speaker could analyse his own language. of course information must come from a native speaker, but the above restriction also limits knowledge. We gain insight from the outside looking in as well as from the inside looking out. (Mary Haas 1984: 69 emphasis added FKA). 


\section{Notes}

1. Some of the ideas expressed here were first aired in an invited contribution to a workshop on 'The best record' organised by the then Cognitive Anthropology Group (now the Language and Cognition Group) at the Max Planck Institute for Psycholinguistics, Nijmegen, in October 1995. I am grateful to the audience at that workshop for their comments and enthusiastic reception of the ideas. I am especially indebted to David Wilkins for the invitation, suggestions and discussions on the topic. I salute the many non-native speakers who have worked and continue to work on Ewe, my language. I am also grateful to Alan Dench and Nicholas Evans for comments on earlier versions of the chapter.

2. In the post-modernist turn one does not expect anybody to be able to evaluate any ethnography objectively. Ethnographic descriptions are seen more as accounts of particular practices within communities of practice including the ethnographer as an agent.

3. I should point out that this term which literally means 'on a person' is archaic and thanks to Westermann's record some of us know the term today. The modern term used for twenty is blá-eve literally 'tie two', also reflecting another reckoning practice of counting in sets of ten.

4. The following abbreviations are used in the interlinear glosses: $A B L=$ ablative preposition; $\mathrm{ALL}=$ allative preposition, $\mathrm{COP}=$ copula; $\mathrm{CQ}=$ content question marker; DAT $=$ dative preposition; $\mathrm{DEF}=$ definiteness marker; DEM $=$ demonstrative; DISJ $=$ disjunctive $;$ aFOC $=$ argument focus marker; $\mathrm{HAB}=$ habitual aspect marker; INDEF = indefiniteness marker; LOC = locative preposition; LOG = logophoric pronoun; NEG = negative; NPRES = nonpresent; $\mathrm{PFV}=$ perfective aspect marker; $\mathrm{PL}=$ plural marker; poss $=$ possessive linker; POT = potential; PRED = predication marker PRES = present; PROSP = prospective aspect marker; $\mathrm{Q}=$ question particle; $\mathrm{QV}=$ quotative marker; RED = reduplicative formative; REL = relative clause introducer; $\mathrm{REP}=$ repetitive; $\mathrm{SG}=$ singular; $\mathrm{TRIP}=$ triplicative $; 1=$ first person; $2=$ second person; 3 = third person.

High tones are marked throughout with an acute accent in addition to the low tones that are customarily marked in the traditional orthography with a grave accent. The hacek marks a rising tone. Ewe orthographic $f$ and $\sqrt{ }$ are the voiceless and voiced bilabial fricatives respectively.

Examples are sometimes drawn from Ewe texts. Examples taken from texts that are available in electronic format are referred to by the author, year 
and the concordance line in square brackets (e.g. Hlomatisi 1994 [001]). Examples taken from texts that are available in paper form are referred to in the normal author plus date and page number fashion. Examples without any reference are supplied by the author.

5. It could also be argued that the different nature of the logophoric pronoun in Ewe and other African languages to the systems from familiar Standard Average European languages played a role in putting it on the linguistic agenda. The comprehensive description by Clements (1979), a non native speaker, has served as an important seminal work in this regard.

6. It appears that the non-nasalisation of mid-vowels in Pekigbe is due to its contact with Twi (Akan) which does not also have nasalised mid-vowels. Peki has some other features which one can attribute to its intensive contact with Akan in the $19^{\text {th }}$ century (see Ameka 2004).

7. The intentional is marked by a locative nominal gé. The locative verb is variable. The most frequent are 'lè', 'no', 'yi' [...], 'dè' (go, reach) and 'gbona' (returning) (my translation).

8. These are the two verbs in the languages which, in the habitual, have a progressive reading and it is the progressive reading that is relevant for the interpretation of the prospective construction as expressing the inchoation of a situation.

9. The same point is made in the English version which is quoted here to serve as a translation of the German text: 'a peculiarity of Ewe is that we often find a row of verbs one after the other. The chief features of this are that all the verbs stand next to each other without being connected, that all have the same tense or mood, and that in the event of their having a common subject and object, these stand with the first, the others remaining bare: should a conjunction stand between two verbs, the subject and object must be repeated. The explanation of this is that the Ewe people describe every detail of an action or happening from beginning to end, and each detail has to be expressed by a special verb: they dissect every happening and present it in its several parts, whereas in English we seize on the leading event and express it by a verb, while subordinate events are either not considered or rendered by means of a preposition, adverb, conjunction or a prefix of the verb.' (Westermann 1930: 126)

10. A development of this kind has occurred in Mparntwe Arrernte (Australian): *kerle-me 'descend' > -kerle 'downwards' (David P. Wilkins p.c.).

11. The disjunctive aló serves to mark disjunction or alternation. To indicate the contrast in the choice, it is preceded by the emphatic morpheme lóo. It is in this combination that we find it in the interrogative utterance (my translation). 


\section{References}

Abasi, Augustine Kututera

1995 'Lua-lia', the 'fresh funeral': founding a house for the deceased among the Kasena of north-east Ghana. Africa 65:448-475.

Aboh, Enoch O.

2001 Review of Anne-Marie Brousseau, Réalisations argumentales et classes de verbes en fongbe. Lingua 111: 759-769.

Aboh, Enoch O., Felix K. Ameka, and James Essegbey.

in press Moving from verbs to prepositions in Gbe (West Africa). In Hubert Cuyckens (ed) Adpositions of movement. Amsterdam: John Benjamins.

Akpatsi, Robert S.

1980 Ame adeke menya etso me o [Nobody knows tomorrow]. Accra: Bureau of Ghana Languages.

Ameka, Felix K.

1988 The grammatical coding of the terminal viewpoint of situations in Ewe. Australian Journal of Linguistics 8: 185-217.

1991 Ewe: its grammatical constructions and illocutionary devices. $\mathrm{PhD}$ thesis. Australian National University, Canberra.

1995 The linguistic construction of space in Ewe. Cognitive Linguistics 6(2/3): 139-180.

1998 Les particules énonciatives en ewe. In Les langues d'Afrique Subsaharienne. S. Platiel and R. Kabore (eds.), 179-204. (Faits de Langues 11-12.) Paris: Ophrys.

1999 Spatial information packaging in Ewe and Likpe: a comparative perspective. In Comparing African spaces. S. Neumann (ed.), 734. (Frankfurter Afrikanistische Blätter 11.) Cologne: Rúdiger Köppe.

2001 Ideophones and the nature of the adjective class in Ewe. In Ideophones, E. F. K. Voeltz and C. Kilian-Hatz (eds.), 25-48. Amsterdam: John Benjamins.

2002 The adjective class in Ewe: its strata and emergent nature. Paper given at an International Workshop on adjective classes. Research Center for Linguistic Typology, La Trobe University, Melbourne August. 
2003 Multiverb constructions in a West African areal typological perspective, Proceedings of the Workshop on Multiverb constructions in constraint based grammars, NTNU Summer School in Linguistics, Trondheim 23-27 June 2003, published at http://ebvarda.hf.ntnu.no/ling/tross

2004. Contact induced grammatical change in the Lover Volta Basin. Paper given at Workshop on Language contact and change in West Africa, University of Vienna, November 11-14 2004

2005 Forms of secondary predication in serializing languages: depictives In Ewe. In, Secondary predication and adverbial modification: The typology of depictives, N. Himmelmann and E. Schultze-Berndt (eds.) 353-376. Oxford: Oxford University Press.

2006 Ewe serial verb constructions in their grammatical context. Serial verb constructions: a crosslinguistic perspective, In A. Aikhenvald and RMW Dixon (eds) 124-143. Oxford: Oxford University Press.

Ameka, Felix K., and M. E. Kropp Dakubu

to appear The progressive and prospective in Dangme and Ewe. In Aspect and modality in Kwa languages of Ghana. F. K. Ameka and M. E. K. Dakubu (eds.).

Ameka, Felix K. and James Essegbey

2006 Elements of the grammar of space in Ewe. In S. C. Levinson and D. P. Wilkins (eds.) Grammars of space, Cambridge: Cambridge University Press.

in press CUT and BREAK verbs in Ewe and the causative alternation construction. Cognitive Linguistics.

Ameka, Felix K, and Eva Schultze-Berndt

2000 Adverbialiser or predicate(ion) marker? Ewe -i and its relatives in a typological perspective. Third World Congress of African Linguistics, Université du Benin, Lome, Togo, 2000.

Amuzu, Evershed

1993 Three place predicates in Ewe. MA thesis,, University of Ghana. Ansre, Gilbert

1961 The tonal structure of Ewe. Connecticut: Hartford Seminary Foundation.

1966a The grammatical units of Ewe. PhD thesis., University of London.

1966b The verbid: a caveat to serial verbal constructions. Journal of West African Languages 3(1): 29-32. 

ern Ewes in Ghana, K. Gavua (ed.), 22-47. Accra: Woeli.

Anttila, Raimo

1972 An introduction to historical and comparative linguistics. New York: Macmillan.

Ayeke, Kodzo

1974 Hlöbiabia [Taking revenge]. Accra: Bureau of Ghana Languages.

Baeta, Lily

1962 Míafe gbe [Our language]. London: Macmillan.

Bamgbose, Ayo

1974 On serial verbs and verbal status. Journal of West African Languages 9(1): 17-48.

Bamgbose, Ayo

1982 Issues in the analysis of serial verb constructions. Journal of West African Languages 12(2): 3-21

Bickerton, Derek

1996 Why serial verb constructions in 'Isle de france Creole' can have subjects: a reply to Crane, Coleman and Curnow. In Changing meanings, changing functions. P. Bakker and A. Syean (eds.), 155-169. London: University of Westminster Press.

Blackings, Mairi and Nigel Fabb

2003 A grammar of Ma'di. Berlin: Mouton de Gruyter

Bolinger, Dwight

1977 Meaning and form. London: Longman.

Capo, Hounkpati B. C.

1985 Determining the third person singular object pronoun in Gbe. In West African Languages in Education. K. Williamson (ed.) pp. 106-131. Wien: Afro Publishers.

1991 A comparative phonology of Gbe. Berlin and Garome: Mouton de Gruyter (Foris) and LABOGBE.

Clements, George N.

1972 The verbal syntax of Ewe. PhD thesis. University of London.

1975 Analogical reanalysis in syntax: the case of Ewe tree-grafting. Linguistic Inquiry 6: 3-51.

1979 The logophoric pronoun in Ewe: its role in discourse. Journal of West African Languages 10(2): 141-177.

Collins, Chris

1993 Topics in Ewe syntax. PhD thesis, Massachusetts Institute of Technology. 
Coulmas, Florian

1981 Introduction: the concept of native speaker. In A festschrift for the native speaker. F. Coulmas (ed.), 1-25. The Hague: Mouton.

Coulmas, Florian (ed.)

1981 A festschrift for the native speaker. The Hague: Mouton.

Crowley, Terry

2003 Serial verbs in oceanic: A descriptive typology. Oxford: Oxford University Press

Crystal, David

2000 Language death. Cambridge: Cambridge University Press.

Davies, Alan

2003 The native speaker: Myth and reality. Clevedon: Multilingual Matters.

Dechaine, Rose-Marie

1993 Serial verb constructions. In Syntax: An International Handbook of Contemporary Reserach. J. Jacobs, ed. pp. 789-825. Berlin: Walter de Gruyter.

Dixon, R. M. W.

1997a The rise and fall of languages. Cambridge: Cambridge University Press.

1997b Mary Haas: A real linguist of the nth degree. Anthropological Linguistics 39(4): 611-616.

2004 The small adjective class in Jarawara. In Adjective classes: a crosslinguistic typology, eds. Dixon Robert M. W. and Alexandra Y. Aikhenvald, 177-198. Oxford: Oxford University Press.

Dogoe, E. Y.

1964 Nya zozo. [Know how to walk]. Accra: Bureau of Ghana Languages.

Dorian, Nancy C.

1981 Language death: the life cycle of a Scottish Gaelic dialect. Philadelphia: University of Pennsylvania Press.

1986 Gathering data in terminal speech communities. In The Fergusonian impact: In Honour of Charles Ferguson. Vol 2 Sociolinguistics and the sociology of language, Joshua Fishman (ed), 555-575. Berlin: Mouton de Gruyter.

van Driem, George

2002 A holistic approach to the fine art of grammar writing: The Dallas manifesto. Paper given at Grammar Writing Symposium, Summer Institute of Linguistics, Dallas.Texas. 
Durie, Mark

1997 Grammatical structures in verb serialisation. In Complex predicates. A. Alsina, J. Bresnan, and P. Sells (eds.), 289-354. Stanford: CSLI.

Duthie, Alan S.

1996 Introducing Ewe linguistic patterns. Accra: Ghana Universities Press.

Essegbey, James

1994 Anaphoric phenomena in Ewe. MPhill thesis. University of Trondheim.

1999 Inherent complement verbs revisited: Towards an understanding of argument structure in Ewe. PhD diss., Leiden University.

2004 Auxiliaries in serializing languages: On COME and GO in Sranan and Ewe. Lingua 114(4): 473-494

Evans, Nicholas

2001 The last speaker is dead - long live the last speaker! In Linguistic fieldwork. P. Newman and M. Ratliff (eds.), 250-281. Cambridge: Cambridge University Press.

Fabb, Nigel

1992 Reduplication and object movement in Ewe and Fon. Journal of African Languages and Linguistics. 13: 1-39.

Gadzekpo, B. S.

1982 Ewots $k u$, equla li. [The producer is dead, the consumer is alive] Accra: Waterville Publishing House. (Second revised edition)

Grinevald, Colette

1998 Language endangerment in South America: A programmatic approach. In Endangered languages, L. Grenoble and L. Whaley (eds.), 124-160. Cambridge: Cambridge University Press.

2003 Speakers and documentation of endangered languages. Language Documentation and Description 1: 52-72.

Haas, Mary R.

1984 Lessons from American Indian Linguistics. In New directions in linguistics and semiotics, James E. Copeland (ed.), 68-72. Houston: Rice University Studies.

Hale, Kenneth

1972 Some questions about anthropological linguistics: The role of native knowledge. In Reinventing anthropology. D. Hymes (ed.), 382-397. New York: Pantheon Books.

Hastrup, Kirsten.

1993 Native anthropology: a contradiction in terms? Folk 35:147-161. 
Heine, Bernd, Ulrike Claudi, and Friederike Hünnemeyer

1991 Grammaticalization: a conceptual framework. Chicago: The University of Chicago Press.

Heine, Bernd, Tom Güldemann, Christa Kilian-Hatz, Donald A. Lessau, Heinz Roberg, Mathias Schladt, and Thomas Stolz

1993 Conceptual shift: a lexicon of grammaticalization processes in African languages. Cologne: Institut für Afrikanistik.

Heine, Bernd, and Tania Kuteva

2002 World Lexicon of Grammaticalization. Cambridge: Cambridge University Press.

Hellwig, Birgit

this vol. Field techniques and grammar writing. In Catching language. F. K. Ameka, A. Dench, and N. Evans, eds.

Hlomatsi, Yao

1994 Agbe nye nusi newəe [Life is what you make it]. Accra: Bureau of Ghana Languages.

Jespersen, Otto J. H.

1933 Essentials of English grammar. London, Allen and Unwin.

Johnstone, Barbara

2000 The individual voice in language. Annual Review of Anthropology 29: 405-424.

Kangni, Atah-Ekoué

1989 La syntaxe du Gen: Étude syntaxique d'un parler Gbe (Ewe): le Gen du Sud-Togo. Frankfurt: Peter Lang.

Keesing, Roger M.

1979 Linguistic knowledge and cultural knowledge: some doubts and speculations. American Anthropologist 81: 14-36

Kruisinga, Etsko

1911 A handbook of present day English. Utrecht, Kennink en Zoon.

Leech, Geoffrey and Jan Svartvik

1975 A communicative grammar of English. London: Longman

Lees, R. B.

1957 Review of N. Chomsky, Syntactic structures. Language 33: 375408.

Lefebvre, Claire

1999 On the empirical reliability of some Haitian data. Journal of Pidgin and Creole Languages 4(2): 379-384.

2000 On data. Journal of Pidgins and Creoles 15(2):313-337.

Levinson, Stephen C.

2000 Presumptive meanings. Cambridge, Mass: MIT Press 
Lewis, Marshall

n.d. Ewe relativization, NP accessibility and universal grammar: Department of Linguistics, Indiana University [1985].

Lord, Carol

1993 Historical change in serial verb constructions. Amsterdam: John Benjamins.

Makkai, Adam

1972 Idiom structure in English. The Hague: Mouton.

McLauglin, Fiona, and Therno Seydou Sall

2001 The give and take of fieldwork: noun classes and other concerns in Fatick, Senegal. In Linguistic fieldwork. P. Newman and M.

Miestano, Matti M. Ratliff (eds.), 189-210. Cambridge: Cambridge University Press.

2004 Review of Blackings and Fabb A grammar of Ma'di. LinguistList Issue 14.3284

Mithun, Marianne

2001 Who shapes the record: the speaker and the linguist. In Linguistic fieldwork. P. Newman and M. Ratliff (eds.), 34-44. Cambridge:

Mosel, Ulrike Cambridge University Press.

this vol. Grammaticography: The art and craft of grammar writing.

Nichols, Johanna

1982 Ingush transitivisation and detransitivisation. Berkeley Linguistics Society 8: 445-462.

Nichols, Johanna, David A. Peterson and Jonathan Barnes

2004 Transitivising and detransitivising languages. Linguistic Typology 8(2): 149-211

Nukunya, G. K

1994 Insider anthropology: The case of the Anlo Ewe. Ethnofor 7(1): 24-40.

Newman, Paul (1999). "We has seen the enemy and it is us": The endangered language issue as a hopeless cause. Studies in the Lingusitic Science 28 (2): 11-20.

2003 The endangered languages issue as a hopeless cause. In Language death and language maintenance: theoretical, practical and descriptive approaches, Mark Janse and Sijmen Tol (eds.), 1-13. Amsterdam, John Benjamins.

Nida, Eugene A.

1981 Informants or colleagues? In A festschrift for the native speaker, Florian Coulmas (ed.), 169-174. The Hague, Mouton. 
Owusu, Maxwell

1978 Ethnography of Africa: the usefulness of the useless. American Anthropologist 80: 310-334.

Owusu, Maxwell

1997 Ethnography of Africa: the usefulness of the useless. In Perspectives on Africa: a reader in culture, history and representation. Roy Richard Ginker and Christopher B. Steiner (eds.), 704-723. Oxford: Blackwell (a slightly edited version of Owusu 1978).

Pool, Robert

1989 There must have been something ... Interpretation of illness and misfortune in a Cameroonian village. PhD thesis. University of Amsterdam.

Quirk, R, S. Greenbaum, G. Leech and J. Svartvik

1985 A comprehensive grammar of the English language. London: Longman.

Rongier, Jacques, Ewonuku K. Tsevi, and Kodzo Anika

1990 Apprenons l'Ewe: Miasr ${ }^{\sim} E$ egbe, Vol 4. Paris: L'Harmattan.

Ryang, Sonia.

1997 Native anthropology and other problems. Dialectical Anthropology 22:23-49.

Sadock, Jerry M.

1996 PIFL: The Principle of Information-Free Linguistics. Chicago Linguistic Society 32 (Parasession on Theory and Data in Linguistics): $133-138$.

Sebba, Mark

1987 The syntax of serial verbs: an investigation into serialisation in Sranan and other languages. Amsterdam: John Benjamins.

Schneider, David

1968 American kinship: a cultural account, Englewood Cliffs, NJ.: Prentice-Hall

Tedlock, Denis

1987 Questions concerning dialogical anthropology. Journal of Anthropological Research 43 (4): 325-337.

Thompson, Sandra A, and Paul J. Hopper

2001 Transitivity, clause structure, and argument structure: evidence from conversation. In Frequency and the emergence of linguistic structure. J. Bybee and P. J. Hopper (eds.), 27-60. Amsterdam: John Benjamins. 
Ulvestad, B.

1981 On the precariousness of linguistic introspection. A festschrift for the native speaker, Florian Coulmas (ed.), 245-262. The Hague: Mouton.

Warburton, Irene P. et al.

1968 Ewe basic course. Bloomington: Indiana University Linguistics Club.

Westermann, Diedrich H.

1905 Wörterbuch der Ewe-Sprache. Teil 1 Ewe-Deutsches Wörterbuch. Berlin: Dietrich Reimer.

1907 Gramatik der Ewe-Sprache. Berlin: ReimerWestermann, Diedrich 1930 A study of the Ewe language. Oxford: Oxford University Press.

Westermann, Diedrich

1954 Wörterbuch der Ewe-Sprache. Berlin: Akademie Verlag.

Widlok, Thomas

2004 Ethnography in language documentation. Language Archive Newsletter 1:4-6.

Wierzbicka, Anna

1988 The semantics of grammar. Amsterdam: John Benjamins.

in press English: Meaning and Culture. New York: Oxford University Press

Zandvoort, Reinard W.

1948 A handbook of English grammar. Groningen, Wolters. 